\title{
Sources of Global Private Capital Flows: What Developing Countries Can Do to Attract, Manage, and Retain Global Private Capital Flows to Finance Economic Growth and Sustainable Development
}

\author{
Ashford C. Chea \\ School of Business, Kentucky Wesleyan College \\ 4721 Covert Avenue, Evansville, IN 47714, USA
}

Tel: 812-471-9341Ｅ-mail: achea@ix.netcom.com

Received: August 262010 Accepted: September 9, 2010 doi:10.5296/ber.v1i1.993

\begin{abstract}
The author begins the paper with a brief historical perspective of global capital flows to developing economies. He then presents the theoretical underpinnings and methodology employed during the research. This is followed by the review of the literature. Next, the researcher outlines his findings. He also analyzes economic strategies to attract global private capital flows and policy implications for decision makers in developing economies. The author ends the paper with some policy recommendations and the way forward for economic growth and sustainable development.
\end{abstract}

Keywords: Global, Private, Capital Flows, Developing Countries, Economic Growth

\section{Introduction}

Contrary to popular perceptions, bilateral donors and international financial institutions are no longer the main sources of funding (including capital flows and transfers) for investment and growth in developing countries. More of the six-fold increase in inflows since 2000 came from the private sector - a sharp departure from the previous decade (Sayeh, 2011). Private financial inflows to developing countries expanded rapidly over the previous decade and sub-Saharan Africa shared in the boom. Globally, total gross private inflows to emerging and developing countries rose from \$151bn in 2002 to a peak of \$1.7tn in 2007 or from \$49bn to $\$ 674 \mathrm{bn}$ in net terms. Foreign direct investment, the mainstay of investment flows to developing countries, nearly tripled. Even more dramatic was the explosive growth of 
portfolio (both debt and equity) and other flows (mainly bank loans and trade credits, from negligible amounts in 2002 to \$1.1tn in 2007-65 percent of total capital inflows. All developing regions shared in the surge (Regional Economic Outlook, 2010).

During the 1990s, net capital flows to developing countries increased markedly. In 1996, net private capital flows were \$190bn, almost four times larger than in 1990. During 1990-97, annual net private capital inflows were also larger than those preceding the 1982 debt crisis, and more heavily concentrated. Five countries accounted for 75 percent of total inflows. Most of the surge was concentrated in Asia and Latin America. Consequently, 140 of 166 developing nations collectively accounted for less than 5 percent of total inflows (Lopez-Mejia, 1999). However, over the past 25 years, foreign direct investment (FDI) in low-income developing countries has increased. This is even true for sub-Saharan Africa (SSA). Foreign direct investment in the region has increased substantially, from \$11.8 billion in 1980 to $\$ 25.6$ billion in 1990 and to more than \$101 billion in 2004. Moreover, as a percent of gross domestic product (GDP), the stock of FDI in SSA increased from 10.2 percent in 1980 to 29.4 percent. A new source of funding has emerge as well-from a small number of investors who are interested in adding to their portfolios debt securities issued by governments in the region (McDonald, Treichel, and Weisfeld, 2006).

The composition and sectoral destinations of capital flows during the 1990s surge were different from those during that preceded the 1982 debt crisis. In 1970s, bank lending was the larger component of capital flows, the most important recipient of which was the public sector. In the 1990s, by contrast, the surge was dominated by bonds, foreign direct investment (FDI), and the private sector did most of the external borrowing (Lopez-Mejia, 1999).

The objectives of the paper are to analyze (1) sources of global private capital flows; (2) causes of global private capital flows (3) Reversal of global private capitals; (4) consequences of excessive inflows of private global capital, and (5) policies that developing countries can implement to attract, manage, and retain private global capital flows.

\section{Theoretical Underpinnings}

Economy theory suggests that capital will move from countries where it is abundant to countries where it is scarce because the returns on new investment opportunities are higher where capital is limited. Such a reallocation of capital will boost investment in the recipient country and, as Summer (2000) suggests, bring enormous social benefits. Underlying this theory is the premise that returns to capital decrease as more machinery is installed and new structures are built, although, in practice, this is not always, or even generally, true. New investment is more productive in countries with a skilled workforce and well-developed physical infrastructure, as Lucas (1990) recognized in explaining why capital does not flow from rich to poor countries. Thus, a consistent finding is that new capital flows tend to go to countries that have received large flows in the past and that investors also seek favorable business environments (Mody and Srinivasan, 1998).

Although economy theory and empirical investigations have much to say about where international capital may flow, both theory and the evidence are less definitive about the 
impact of such flows. Once in a country, private capital may increase either domestic consumption or investment, or it may principally increase the county's foreign exchange reserves. If flows are driven merely by incentives to evade taxes or jump other legal barriers, money may flow out of a country as quickly as it flows in (Mishra, Mody, and Murshid, 2001). Despite these ambiguities, private capital flows are generally found to have significant impact on domestic investment, with the relationship being strongest for FDI and international bank lending (syndicated lending) and weaker for portfolio flows (Bosworth and Collins, 1999).

Therefore, it is natural to expect that as financial globalization-cross-border flows of various forms of financial capital-picks up steam, these flows from industrial to developing countries will increase, making all countries better off (Prasad, Rajan, and Subramanian, 2007).

\section{Methodology}

This paper relied on the literature review of current relevant articles focusing on sources of global private capital for financing development in developing countries. Except where a source was needed specifically for its perspective on broad issues relating to capital flows to developing countries, the author screened papers by "global private capital flows" and by numerous variants of keywords, focusing specifically on developing economies. Source papers included refereed research studies, empirical reports, and articles from professional journals. Since the literature relating to global private capital flows is voluminous, the author used several decision rules in choosing articles. First, because capital flows is changing fast in today's environment, the author used mostly sources published from 2000-2011, except where articles were needed specifically for their historical perspectives. Second, given the author's aim to provide a practical understanding of the main issues in global private capital flows to developing economies, he included, in order of priority: refereed empirical research papers, reports, and other relevant literatures on current trends in global capital flows to developing countries. To get some perspective on the current state of global private capital flows to developing countries, the author began with a review of the current literature.

\section{Literature Review}

\subsection{Causes of Global Private Capital Inflows to Developing Countries}

The responsiveness of private capital to opportunities in emerging and developing markets started to improve in the 1990s because of both internal and external factors. Internal factors improved private risk-return characteristics for foreign investors through three main channels. First, creditworthiness improved as a result of external debt restructuring in a wide range of countries. Second, productivity gains were obtained from structural reforms and the establishment of confidence in macroeconomic management in several developing countries that had undertaken successful stabilization programs. Third, countries adopting fixed exchange rate regimes became increasingly attractive to investors owing to the transfer of the risk of exchange rate volatility — at least in the short run — from investors to the government. 
In addition, both cyclical and structural, external influences played a significant role in the capital surge of the 1990s. Cyclical forces were the dominant explanation in the early 1990s, when the decline in world real interest rates "pushed" investors to emerging and developing markets. The structural external forces started to work when two developments in the financial structures of capital-exporting countries increased the responsiveness of private capital to cross-border investment opportunities. First, falling communication costs, strong competition, and rising costs in domestic markets led firms in industrial countries to produce abroad to increase their efficiency and profits. Second, institutional investors became more willing and able to invest in developing countries because of their higher long-term expected rates of return, wider opportunities for risk diversification owing to their broader and deeper securities markets, and greater feasibility of investing as their capital accounts were liberalized.

\subsection{Understanding Reversals of Global capital Flows}

Major reversals of capital flows occurred in a number of developing countries even before the 1990s. A common reason for the reversals has been a lack of confidence in domestic macroeconomic policies, leading to speculative attacks on currencies and balance of payments crises. Balance of payments crises can also result from financial vulnerabilities or other factors that make macroeconomic policy less credible. In particular, if a country's banking sector is weak; its authorities might prefer to devalue rather than to increase interest rates. Moreover, the maturity and currency composition of the public sector's liabilities relative to those of its assets are particularly relevant. In fact, even if a country's public sector is solvent, it might be vulnerable to short-run liquidity crises if creditors prove reluctant to refinance the government’s short-term liabilities (Lopez-Mejia, 1999).

\subsection{Consequences of Excessive Global Capital Inflows}

As noted above, investors' interest in developing countries has led to their increased financial integration. Large capital inflows, however, might also imply an excessive expansion of aggregate demand and have negative effects on the financial sector. In addition, macroeconomic distortions can amplify capital flows and their impact on the economy. Below are two potential hazards associated with excessive capital inflows.

Overheating: Capital inflows may lead to excessive expansion of aggregate demand or macroeconomic over-heating. This expansion is likely to be reflected in inflationary pressure, real exchange rate appreciation, and widening current account deficits.

Effects of Capital Inflows on Financial Sector: Capital inflows affect the financial system that intermediate them. They have two major effects on the domestic banking system. First, under a pegged exchange rate regime, the quasi-fiscal deficit—which includes financial transactions undertaken by central banks and other public financial institutions that play the same roles as taxes and subsidies-increases as a result of a sterilization policy that sells high yielding domestic bonds and buys foreign exchange holdings earning lower interest rates. Second, the financial system might become more vulnerable because of a rise in lending that exacerbates 
the maturity mismatch between bank assets and liabilities and reduces loan quality (Lopez-Mejia, 1999).

\subsection{Alternative Sources of Global Private Capital Inflows to Finance Development}

\subsubsection{Foreign Direct Investment (FDI)}

FDI occurs when new companies are set up or existing companies are taken over by foreign enterprises in developing countries.

FDI has proved to be resilient during financial crises. For instance, in East Asian countries, such investment was remarkably stable during the global financial in 1997-98. In sharp contrast, other forms of private capital flows-portfolio equity and debt flows, and particularly short-term flows-were subject to large reversals during the same period ( Dadush, Dasgupta, and Ratha, 2000; Lipsey, 2001). The resilience of FDI during financial crises was also evident during the Mexico crisis in 1994-95 and the Latin American debt crisis of the 1980s.

In addition to these advantages, Feldstein (2000) notes that the gains to host countries from FDI can take several other forms:

FDI allows the transfer of technology-particularly in the form of new varieties of capital inputs - that cannot be achieved through financial investments or trade in goods and services. FDI can also promote competition in the domestic input market.

Recipient of FDI often gain employee training in the course of operating the new business.

Profits generated by FDI contribute to corporate tax revenues in the host country. In principle, therefore, FDI should contribute to investment and growth in host countries through these various channels.

\subsubsection{Disadvantages of Foreign Direct Investment}

One striking feature of FDI flows is that their share in total inflows is higher in riskier countries, with risk measured either by countries' credit ratings for sovereign debts or by other indicators of country risk. There is also some evidence that its share is higher in countries where the quality of institutions is lower.

Also, the transfer of control may not always benefit the host country because of the circumstances under which it occurs. Krugman (1998) notes that sometimes the transfer of control occurs in the midst of a crisis and asks:

"Is the transfer of control that is associated with foreign ownership appropriate under these circumstances? That is, are foreign corporations taking over control of domestic enterprises because they have special competence, and can run them better, or simply because they have cash and the locals do not? Does the fire sales of domestic firms and their assets represents a burden to the afflicted countries, over and above the cost of the crisis is itself?”

Other considerations: There are some other cases in which FDI might not be beneficial to the recipient country - for instance, when such investment is geared toward serving domestic 
markets protected by high tariff or nontariff barriers. Under these circumstances, FDI may strengthen lobbying efforts to perpetuate the existing misallocation of resources. There could also be a loss of domestic competition arising from foreign acquisitions leading to a consolidation of domestic producers, through either takeover or corporate failures (Loungani and Razin, 2001).

\subsection{Portfolio Investment (Debt)}

Portfolio debt investment occurs when a foreign entity purchases debt securities such as bonds issued by another country or an institution in another country.

Developing countries have generally welcomed the inflows of foreign portfolio debt investment, which they often see as a vote of confidence in their economic management. Portfolio debt investment has helped lower government borrowing costs by exerting downward pressure on domestic interest rates. It has also helped increase market efficiency by increasing the number of bidders for government securities and by adding liquidity (McDonald, Treichel, and Weisfeld, 2006). But there are risks, too. Volatile private debt capital inflows can complicate the management of exchange rate and monetary policy. The financial markets of most developing countries are small in relation to the large amounts of liquidity available globally. As the experience of other developing countries show, portfolio capital inflows can reverse rapidly, leading to large swings in exchange and interest rates.

The good news is that some investors are showing more interest in debt instruments issued by developing countries. Why? First, investors have widened their search for yield in a global environment of ample liquidity and historically low interest rate spreads between the government securities of developing and those of industrial countries. Second, risk premiums on government debt have fallen in some developing countries. Improved macroeconomic performance in many has increased their ability to carry debt. Third, there may be expectations that the currencies of commodities-exporting countries could appreciate as a result of rising commodities prices (McDonald, Treichel, and Weisfeld, 2006).

\subsection{Portfolio Investment (Equity)}

Portfolio equity investment occurs when foreign entities invest in a local stock market by buying shares in local companies. However, the number of developing countries with stock markets is very few. Moreover, most of them are very small or underdeveloped to absorb relative large portfolio equity investment. For instance, the number of stock markets in sub-Saharan African countries has risen from five in 1989 to sixteen today. While foreign capital flows have helped stimulate this growth, in most cases, these markets remain too small and illiquid to attract more significant foreign investment. Except for South Africa and Nigeria, the markets are small. Most have few listed companies, and at about 20 percent of GDP in 2008 (excluding South Africa) average market capitalization is lower than in most developing and emerging markets. Market liquidity is less than 10 percent of the value of shares actually traded each year. Such low business volumes make it difficult to support a local market with its own trading system, market analysis, and brokers. Small size and lack of liquidity also deter foreign investors: the exposure of foreign institutional investors is 
typically negligible until a market reaches about $\$ 50 \mathrm{bn}$ in size or $\$ 10 \mathrm{bn}$ in shares traded annually (Andrianaivo and Yartey, 2009).

Therefore, reforms in a range of areas could support development of the region and other developing countries with similar market conditions and in turn contribute to economic growth and sustainable development. Steps to improve the legal and accounting framework, private sector evaluation capabilities, and public sector regulatory oversight would also be beneficial. Appropriate sequencing of reforms is important: stock markets tend to develop only after financial sectors have reached a certain depth (Dorsey, 2008).

Opening up to foreign investors tends to be helpful only in countries that have little political risk and sufficiently high income (Andrianaivo and Yartey, 2009). Good-quality institutions, such as rule of law, democratic accountability, and limited corruption, are important in reducing risk and enhancing the viability of external finance. The development of regional markets may also be a way to promote cost efficiency and overcome small market size.

\subsection{International Bank Lending (Loan)}

Another noteworthy financial trend in the 1990s was a substantial increase in the share of private borrowing - especially by banks - in total borrowing. An examination of syndicated loan transactions reveals that more than 42 percent of short-term syndicated loans to developing markets have gone to financial institutions. Almost one-third of short-term syndicated debt has been contracted by commercial banks. Short-term lending by international banks increased rapidly despite a decline in the share of bank lending in total private debt flows to developing countries. The flat or declining indebtedness of developing countries relative to their export earnings and GDP contributed to this development. The growth of developing countries' short-term debt thus reflected the fact that international banks were making more short-term loans even as they were reducing their overall lending to developing countries (Dadush, Dasgupta, and Ratha, 2000).

Short-term international debt is defined as cross-border debt with a maturity of one year or less. There are currently two conventions for defining short-term debt. The Bank for International Settlement (BIS) uses the "remaining maturity" concept-that is, all cross-border debt falling due within one year is counted as short-term debt, regardless of its original maturity. As defined in the World Bank's publication Global Development Finance, however, short-term debt comprises only cross-border liabilities (including official trade credits extended to developing countries as reported by the Organization for Economic Cooperation and Development) with original maturities of one year or less.

One potential advantage of global financial integration may be the enlarged access it gives countries to smooth consumption by using short-term loan in the face of adverse economic shocks. But the advantage of contracting short-term debt for countercyclical purposes can be wiped out if lenders' decision, changes in risk perceptions, and other factors make access to such short-term capital flows pro-cyclical. Moreover, shocks may attract large capital inflows and encourage consumption and investment at levels that are unsustainable in the longer term, and countries may be forced to over-adjust to adverse shocks when capital flees. 
Short-term capital flows appear to be pro-cyclical in developing countries, increasing when economic growth is cyclically faster and declining when growth rates falter. In addition, short-term lending is driven by external or "push" factors. For instance when short-term interest rates-drop in industrial countries it causes an expansion in global liquidity; some of this encourage short-term lending to developing countries.

Two reasons may explain the pro-cyclical behavior of short-term capital flows. First, economic shocks tend to be large and more frequent in developing countries, reflecting these countries narrower economic bases and greater dependence on primary commodity exports. Adverse shocks cause a country's creditworthiness to be downgraded. Changes in risk perception and rating downgrades can lead to rationing of credit to marginally creditworthy borrowers, and such changes can worsen rather than smooth their adjustment. Second, these negative effects are exacerbated by the asymmetry of information available to borrowers and lenders, which may trigger herd behavior as panicked investors rush to withdraw their capital in response to an adverse shock.

Of the different types of private capital flows discussed so far, short-term loans are the most likely to be withdrawn during difficult times. This is because the cost of pulling out is minimal for lenders of short-term debt, whereas liquidating FDI may involve selling plant and machinery, and selling stocks or bonds during a crisis usually involves a loss for the sellers (Dadush, Dasgupta, and Ratha, 2000).

Given the risks that short-term debt poses for developing countries, it is essential that they monitor such debt (particularly debt intermediated by domestic banks) closely and manage it effectively to avoid currency and liquidity crises. Domestic policies that encourage short-term borrowing-either directly through tax incentives or low reserve requirements, or indirectly through pegged exchange rates and sterilization on inflows - should be avoided. Moreover, excessive short-term borrowing for financing long-term investments (such as lending to property sector) should be discouraged. In short, developing countries need to strengthen prudential controls on cross-border borrowing (Dadush, Dasgupta, and Ratha, 2000).

In sum, international debt flows, especially of the short-term variety is risky. It is driven by speculative considerations based on interest rate differentials and exchange rate expectations, not on long-term considerations. Its movement is often the result of moral hazard distortions such as implicit exchange rate guarantees or the willingness of governments to bailout the banking system. It is the first to run for the exits in times of trouble and is responsible for boom-bust cycles of the 1990s (Hausmann and Fernandez-Arias, (2000).

\subsection{Innovative Sources of Private Capital for Development}

Developing countries have an outstanding short-term debt of nearly a trillion dollars. According to the World Bank, they face a financing gap of $\$ 370-\$ 700 \mathrm{bn}$. Given the severe crisis of confidence in debt markets, it will be extremely difficult for countries to obtain private financing using traditional financial instruments. Innovative financing approaches are required, especially for private sector borrowers in developing countries, who face ever harsher credit rationing than public sector borrowers. 
Some innovative market-based financing mechanisms that developing countries could use include borrowing from their expatriate (Diaspora) communities, issuing bonds indexed to growth, and securitizing future revenues. For instance, preliminary estimates suggests that Sub-Saharan African countries could rise \$5-\$10bn by issuing Diaspora bonds and \$17bn by securitizing future remittances and other future receivables (Ramachandran, Gelb, and Shah, 2009).

\subsubsection{Diaspora Bonds}

The rationale behind Diaspora bonds is twofold. For the countries, Diaspora bonds represent a stable and cheap source of external finance, especially in times of financial stress. For investors, Diaspora bonds offer the opportunity to display patriotism by helping their country of origin. Furthermore, the worst-case scenario for Diaspora bond is that debt service payments by the issuer are in local rather than hard currency. But because Diaspora bond investors often have liabilities in their country of origin, they are likely to view the risk of receiving payments in local currency with much less trepidation than would non-Diaspora investors. Among countries with large Diaspora communities are the USA, Britain, Germany, France, the oil-rich Gulf countries, and South Africa (Kelkar and Ratha, 2009).

\subsubsection{Performance-Indexed Bonds}

Debt service payments on fixed-coupon bonds can conflict with a country's ability to pay. When an internal or external shock cuts growth, revenue falls and social safety net expenditures rise. The resulting increase in fiscal pressure can force a country to choose between defaulting on foreign debt and adopting policies that increase the funds available for debt service but exacerbate the decline in output. Growth-indexed bonds are designed to overcome this problem. Coupons on such bonds are set to vary according to the growth performance of a country's GDP, a proxy for its ability to pay. This feature lets a developing country to follow countercyclical fiscal policy, paying less during an economic slowdown and more during an expansion. It is plausible that developing countries would be willing to pay a higher rate on indexed bonds than they would pay on fixed-coupon bonds to be able to avoid potential debt defaults.

This idea has been around for a while, but despite their apparent attractiveness, growth-indexed bonds have not caught on. Widespread use of growth-indexed bonds has been held back because of concerns regarding the accuracy of GDP data, the potential for deliberate underreporting of growth, and the complexity of the bonds. These obstacles are not overwhelming, but the liquidity of growth-indexed bond has been low so far, and there appears to be a novelty premium (Costa, Chamon, and Racci, 2008).

Similar to the growth-indexed bonds issued by sovereigns, sub-sovereign borrowers could issue performance-indexed bonds. A performance-indexed bond would be linked to a well-defined indicator of the performance of the borrowing entity. For a provincial or municipal government, for example, it could be a fiscal revenue target; for a public sector port authority, the indicator could be clearance or transit time; and for a private corporation, it could be earnings (Ramachandran, Gelb, and Shah, 2009). Such instruments have not yet 
been tested, buy they seem potentially useful for large sub-sovereign borrowers in developing markets (Kelkar and Ratha, 2009).

\subsubsection{Future-Flow Securitization}

Securitization is a much maligned term at present because the global crisis had its roots in securitized debt in the USA. Securitization, however, was not the main problem. It was overaggressive valuation of the underlying assets. As long as this error is not repeated and ample excess coverage is provided to allow for decline in the value of the underlying collateral, debt securitized by future hard-currency receivables will be a viable option for developing countries seeking to raise funds in the prevailing environment of low global risk appetite.

By pledging future hard-currency receivables, securitized transactions subordinate the interests of current and future creditors. In a world of perfect capital markets, this might raise the cost of future borrowing and eliminate the rationale for securitization (Chalk, 2002). But many developing countries face capital markets that are far from perfect and creditors may have trouble distinguishing between good and bad risks, paving the way for securitization. The transactions backed by future revenue streams are structured so that the payments do not enter the issuer's home country until obligations to bond investors are met. Although this structure reduces sovereign transfer and convertibility risks, several other risks remain. These include: (a) performance risk associated with the issuing entity's ability to generate the receivables; (b) product risk associated with the stability of receivable flows because of price and volume fluctuations; and (c) diversion risk if the issuer's government forces sales to customers not designated to direct their payments into the trust.

Many of these risks can be reduced through the selection of future-flow receivables and excess coverage. The latter has now become critical as a result of the recent dismal performance of mortgage-backed securities. Unlike the securitization of existing assets such as local-currency mortgage loans, future-flow securitization structures (involving foreign-currency export revenue or diversified payment rights) have held up very well during this financial crisis. Still, issuance of securitized bonds is far below potential. Constraints include a lack of good receivables and strong (investment-grade) local entities and the absence of clear laws, particularly bankruptcy laws. There are, however, fewer barriers today than a decade ago (Kelkar and Ratha, 2009).

In sum, like earlier financial innovations, Diaspora bonds, future-flow-backed securities, and performance-indexed bonds facilitate access to funding for developing countries. Future-flow securitizations are designed to transfer credit risk from borrowers, thereby enhancing credit ratings and expanding liquidity. Diaspora bonds are meant to enhance liquidity. Growth-or performance-indexed bonds are designed to reduce credit by linking coupons to the ability to pay and to enhance liquidity by giving creditors an option on the performance of sovereign and sub-sovereign borrowers in developing countries (Kelkar and Ratha, 2009).

\subsection{Remittances}


Remittances, funds repatriated by migrant workers to family and friends back home, provide the most tangible link between migration and development. But only 3 percent of the world's population has migrated to another country, so migration cannot substitute for domestic development and job creation except in tiny countries. Because remittances are unilateral transfers-gift, if you will-they do not create liabilities. And they usually come with advice - from migrants who have seen better-on how to best use them. Thus remittances are not simply money, but value-added money.

Officially recorded remittances to developing countries reached \$330bn in 2008. The true size, including unrecorded formal and informal flows, is believed to be significantly larger. Remittances total at least three times official development assistance and are the largest source of external financing in many developing countries. In India, remittances exceeded \$50bh in 2008, surpassing all official and private capital flows (Ratha, 2009).

Remittances are closely associated with outward migration, but policies matter, too. Lower transaction costs and the absence of exchange restrictions, black market exchange rate premiums, and unstable macroeconomic environments have been associated with higher remittances (IMF, 2005). But, these studies are drawn mostly from the experiences of migrants from middle income countries, and more work is needed to assess the applicability of this literature to developing countries (Suro et al., 2002; Fajnzylber and Lopez, 2007).

However, in any case, there is a broad consensus that remittance are less volatile than other private capital flows (Buch and Kuckulenz, 2004) and that remittances tend to move counter-cyclically with recipient country income (Chami, Fullenkamp, and Jahjah, 2005).

Furthermore, Remittances tend to be a stable source of foreign exchange earnings. Migrants usually send more money when the family back home experiences hardships, for whatever reason, and therefore remittances act as insurance against economic adversity. Also, remittances have been remarkably resilient during global economic crises. Newly available estimates show that remittances fell by 6 percent in 2009-compared with a one-third in FDI and a near-total collapse of private portfolio flows. Likewise, remittances have proved a lifeline to the poor in conflict countries such as Haiti and Somalia.

In sum, remittance reduces poverty, increase welfare, and provide foreign currency that enables countries to pay for essential imports and service external debt. That in turn improves access to international capital markets. Commercial banks in several countries-including Brazil, Mexico, and Kazakstan-have used future flows of remittances as collateral to raise billions of dollars in financing at cheaper interest rates and longer maturities (Ratha, 2009).

\subsubsection{Critiques of Remittances}

There are critiques of remittances. At a macroeconomic level, large sustained remittance flows may lead to currency appreciation, with adverse consequences for exports. Some researchers say remittances allow governments to delay public investments (such as schools or roads) or push off long-term economic reforms. There is little empirical support for this position, mainly because of the methodological difficulties associated with reverse causality: 
poor countries with weak institutions and low economic growth tend to receive large remittances. The chain runs from weak institutions to large remittances, not the reverse.

Moreover, some analysts say remittances dampen growth because recipients may become dependent on them and work less. Evidence is inconclusive, in part because remittances have their greatest impact during economic downturns when jobs decline and in part because any effect on permanent behavior takes root over a long time. On the other hand, because remittances finance education and health and alleviate credit constraints for small entrepreneurs, they may enhance growth. To the extent that they increase consumption, remittances may increase individual income levels and reduce poverty, even if they do not directly improve growth (Ratha, 2009).

Finally, an even more insidious effect of remittances on economic development and well-being is their impact on institutions and governance. A remittance-receiving household no longer has to care as much about the quality of the government and its ability to provide infrastructure and institutions that facilitate growth. If conditions are bad at home, families send more members abroad and use remittance income to compensate for the lack of government services. They lose interest in pressuring the government to deliver better services. The government, for its part, does not feel compelled to provide these services because it realizes that these households can fend for themselves, and the quality of government declines even further. Hence, remittances are not the highway to a better future. They are a wobbly crutch that millions of people must rely on because there are no better ways to support themselves in their country. The vast expansion of remittances should not be taken as a positive sign of better times ahead, but as a reprimand to policymakers, who should be working harder to improve opportunities for their citizens at home (Chami and Fullenkamp, 2009).

\section{Findings}

To what extent is there empirical support for claims of the beneficial impact of private capital inflows to developing economies?

Empirical analysis-using data from 233 poverty surveys in 76 developing countries, --confirms the poverty-reducing effect of remittances: a 10 percent rise in the remittances-to-GDP ratio is associated with a fall of a little more than 1 percent in the percentage of people living on less than $\$ 1$ a day and the poverty gap (which measures how far below the poverty line the average poor person's income is). Moreover, the research shows that even taking into account the impact of poverty on remittances, in a model in which both poverty and remittances are simultaneously and endogenously determined, the poverty-reducing effect of remittances remains. However, the average remittance-inducing effect is slightly greater (Gupta, Pattillo, and Wagh, 2007).

As for private flows, research show that they have grown more than fourfold since the 1980s. The most striking features of the shift in capital flows to developing countries are the more than tenfold increase in FDI as a share of GDP between the 1980s and 2006. For instance, 
FDI inflows averaged only 0.2 percent of developing countries GDP in early 1980s, but rose steadily to more than 3 percent of GDP by 2006 helping to spur development (Reddy, 2007).

Due to increased inflow of private capital, developing countries have been able to accumulate official reserve. The stock of reserves in developing countries rose from the equivalent of 3.1 months of imports of goods and services in 1995 to 6.5 months by 2006. This self-insurance may be a contributing factor to the reduction in borrowing because the higher reserve levels allow developing countries to forgo borrowing in the event of shocks and draw down reserve instead (Dorsey, 2008).

Finally, a comprehensive study by Bosworth and Collins (1999) provides evidence on the effect of capital inflow on domestic investment for 58 developing countries during 1978-95. The sample covers nearly all of Latin America and Asia, as well as many countries in Africa. The author distinguishes among three types of inflows: FDI, portfolio investment, and other financial flows (primarily bank loans). Bosworth and Collins find that an increase of a dollar in capital flows is associated with an increase in domestic investment of about 50 cents. (Both capital inflows and domestic investment are expressed as percentage of GDP). This result, however, masks significant differences among the types of inflows. FDI appears to bring about a one-for-one increase in domestic investment; there is virtually no discernable relationship between portfolio inflows and investment (little or no impact); and the impact of loans falls between those of the other two. These results hold both for the 58-country sample and for a subset of 18 emerging markets. Bosworth and Collins conclude: "Are these benefits of financial inflows sufficient to offset the evident risks of allowing markets to freely allocate capital across the borders of developing countries? The answer would appear to be a strong yes for FDI.”

\section{Discussion and Analysis}

\subsection{Policy Tools at the Disposal of Developing Economies}

Policymakers have at their disposal countercyclical measures (monetary policy, nominal exchange rate flexibility, and fiscal policy), structural policies (trade policy, banking supervision, and regulation), and capital controls (including the encouragement of gross outflows) to respond to excessive capital inflows. However, no policy recipes can ensure the best use and the most sustained inflow of capital. Successful policy responses have varied across countries and have not relied on a single instrument. Several factors determine the appropriate policy response in a particular country, including its record in fighting inflation, the openness of its economy to foreign trade, the state of public finances, the size and liquidity of the domestic bond market, the health of domestic banks, the flexibility of fiscal policy, and the quality of the regulatory and supervisory framework designed to oversee the financial sector.

The experiences of several developing countries show that individual policies interact in significant ways.

First, they can produce unintended effects on the composition of capital inflows. In particular, a combination of a pegged exchange rate, sterilized intervention, and the absence of capital 
controls on financial flows will probably maximize the volume of short-term capital inflows. Second, interaction among policies can undercut their effectiveness. For example, the high interest rate differentials that usually accompany sterilization might produce an incentive to circumvent capital controls that could offset the contractionary effect of the sterilization efforts (Reinhart and Reinhart, 1998).

A careful sequencing of appropriate policies, therefore, is important in mitigating the risks associated with capital inflows. Research show that successful policy responses in the past used monetary policy in the early stages of the inflow period. However, as inflows persisted and the costs associated with the different types of sterilization were realized, countries began to rely on nominal exchange rate flexibility (Lopez-Mejia, 1999).

\subsection{The Shift to Private Capital Flows}

The dramatic growth in private capital flows to developing countries around the world over the past quarter century is one of the good news stories of development. Capital flows and capital-like flows, such as aid grants and remittances that can substitute for capital flows, are at historic highs, spearheaded by a sharp rise in FDI in developing countries (Feldstein, 2000).

While government-to-government grants and loans to these developing countries have grown only in line with the rise in developing countries' GDP, private-source inflows have quadrupled relative to developing countries GDP since the 1980s, and FDI has risen even more dramatically, helping to spur development. The rise is taking place at a time when promised large increases in official aid to poor countries have so far failed to materialize, and the UN Millennium Development Goals - which include reducing poverty and improving living standards—remain stubbornly out of reach (Dorsey, 2008).

The reasons for the dramatic shift are diverse. Privatization or the opening of the economy to foreign acquisition of existing firms may create one-off opportunities for FDI. In addition, developing countries that had restricted even new Greenfield investment by foreign firms may now be more open. These policies are hard to quantify, but there appears to have been a trend toward liberalization in recent years (Reddy, 2007).

Improvements in the general investment environment, including trade policies and policies affecting the ease and cost of setting up and operating businesses, also help (Busse and Groizard, 2006; Benassy-Quere, Coupet, and Mayer, 2007; and Naude and Krugell, 2007). As with direct regulation of FDI, there has been a trend toward liberalization of trade and the business environment in developing economies that coincides with the increase in FDI.

Broader policy considerations may also encourage investment in developing countries. Inflation and the fiscal and external balances in developing countries have improved in the past decade (Selassie et al., 2006), and this has strengthened the investment environment. Other factors such as political stability are harder to quantify but have undoubtedly promoted greater private capital inflow where conditions have improved. 
Economic developments elsewhere in the world may also have fostered increased private capital inflows. The decline in yield on investments in advanced and emerging market economies has led to a search for higher-yielding investments, including "frontier" developing markets. Also, the rapid increase in assets in sovereign wealth funds has added impetus to the hunt for new investment opportunities in underexplored venues such as the developing countries (Dorsey, 2008).

\subsection{Policymakers need not Panic}

Should policymakers be concerned about the size of these inflows? After all, large or increasing capital inflows often give rise to concerns that the inflows are financing unsustainable current account deficits or increasing countries' vulnerability to capital account crises. Some key considerations in evaluating capital inflows include: (a) whether inflows are financing a large or widening current account deficit; (b) whether they are creating potentially unsustainable debt accumulations; and (c) the extent to which countries are saving some of the inflows in the form of international reserves.

By each of these criteria, the capital and capital-like inflows to developing countries appear benign. The aggregate current account deficits of Developing countries shrank from about 3 percent of their GDP in the mid-1990s to near balance in 2006. Reserve accumulation moved from zero in the late 1990s to steadily increasing inflows, reaching nearly 4 percent of GDP a year by 2006 - providing some insurance against external stocks or a slowdown in inflows. Only a small part of the inflows have been debt- creating because they are dominated by equity, FDI, and transfers. And there is little sign of offsetting non-reserve outflows (for example, capital flight). However, the trends and their policy implications should be interpreted cautiously (Dorsey, 2008).

\section{Policy Recommendations for D eveloping Countries to Attract, Manage, and Retain Global Private Capital Flows}

The key challenge for developing countries policymakers in attracting, managing, and retaining global private capital inflows is to take advantage of these inflows while minimizing the associated risks. To meet this challenge, policymakers should focus on the following:

Strengthen macroeconomic policies: Policies designed to consolidate gains in stability and, in particular, achieve a sustainable fiscal policy will be critical to limiting potential vulnerabilities associated with capital inflows into domestic debt markets.

Enhancing mechanisms to monitor capital inflows and keep track of repayment schedules: At present, some countries do not have full information on capital inflows. There is an urgent need for these countries to gather better information and formulate comprehensive strategies to manage investment inflows.

Reinforcing the supervision of the financial sector so that it can withstand swings in exchange and interest rates: The regulatory authorities need to monitor the balance sheets of financial institutions, including their foreign exchange exposure. 
Deepening domestic debt markets: Most government debt in developing countries has short maturities because of weak domestic demand for instruments with longer maturities. The greater appetite of foreign investors for government paper of longer maturities provides an opportunity to reduce rollover risks of government debt and increase secondary market trading.

Make efficient use of borrowed funds: Governments should use the proceeds of foreign investment in priority social and productive sectors. Particular attention needs to be given to infrastructure bottlenecks for the export sector, where competitiveness may be impaired by exchange rate appreciation in the wake of capital inflows. If developing countries implement these measures, portfolio investment has the potential to raise market efficiency and deepen financial intermediation while safeguarding financial sector soundness (McDonald, Treichel \&Weisfeld, 2006).

\section{Policy Implications}

\subsection{The New Trends in Global Private Capital Inflows}

The recent trends in capital and capital-like flows to developing countries do not appear to carry large risks, but they do present several new challenges for policymakers. First, the shift from official to private financing implies a less direct role for developing countries governments in determining the uses of external financing. The greater stability of these private flows and the fact that the shift to private-to-private flows may empower heretofore underdeveloped developing countries private sectors suggests the trend is a positive development. With the predominance of private flows, the savings-investment and other choices for the use of inflows are being made by private parties, and government influence on these flows diminishes.

Second, the higher private inflows imply more stable and diversified financing for developing countries. However, private inflows may increasingly become the main sources of external vulnerability in developing countries because they could be reversed in a manner not under the control of policymakers. These new inflows may require authorities to reconsider policies to address concerns about sustainability, effects on relative prices and competitiveness, and accompanying policy and institutional reforms.

Third, regardless of data uncertainties, external sector policies in developing countries need to focus on policies relevant to the new inflows. Strong debt management and good donor relations are particularly important for encouraging and managing official lending. However, maintaining a stable macroeconomic environment, a favorable business climate, and efficient mechanisms for international transfers by households are likely to be more important for private inflows (Dorsey, 2008).

\subsection{Dealing with Remittance Flows}

Governments have often offered incentives to increase remittance flows and to channel them to productive uses. But such policies are more problematic than efforts to expand access to financial services or reduce transaction costs. Tax incentives may attract remittances, but they 
may also encourage tax evasion. Matching-fund programs to attract remittances from migrant associations may divert funds from other local funding priorities, while efforts to channel remittances to investment have met with little success. Therefore, efforts to increase savings and improve the allocation of expenditures should be accomplished through improvements in the overall investment climate, rather than targeting remittances (Ratha, 2005).

The bottom line is that remittances cannot be a substitute for a sustained domestically engineered development effort. Moreover, large-scale migration may hurt domestic labor markets in specific sectors, particularly when those leaving are mostly skilled workers. High and rising remittance flows also require policymakers to remain alert to possible Dutch disease effects on the real exchange rate. Nevertheless, migrant transfers can help ease the immediate budget constraints of recipient households. For developing countries as a whole, they are a larger transfer of resources than all development assistance and have a more direct impact on poverty. And the vast, untapped market in money transfer is an opportunity for small savers to gain a foothold in the formal financial sector.

However, bringing recipient households into the formal financial sector is only the first in using remittances more effectively. Country surveys indicate that, although households typically spend a large proportion of their remittances, their propensity to save can be as high as 40 percent. For policymakers, the challenge is to channel these savings into productive uses (Gupta, Pattillo, and Wagh, 2007).

\section{Concluding Remarks}

Aid fatigue and fiscal pressures in the industrial countries have made it more difficult for developing countries to attract capital flows. In such an environment, developing countries have no recourse but to tap private foreign capital to raise productivity levels necessary for sustained increases in living standards. With many Asian and Latin American countries growing rapidly and far ahead of most developing countries in terms of putting in place the financial infrastructure needed to efficiently absorb foreign capital, most developing countries will have to undertake speedy policy and structural reform to attract private flows. Market discipline is likely to be severe in the initial stages, and countries that backtrack on reform will find their access to international capital limited and what is available to them will be provided on costlier terms.

Hence, this requires that developing countries will need to take concerted action on many fronts: Improve infrastructure, strengthen banking systems; develop capital market by accelerating the pace of privatization and broadening the domestic investor base; formulate an appropriate regulatory framework and a more liberal investment regime; introduce competitive labor market policies while creating and maintaining institutions for upgrading human capital; and reform the judiciary system and contain corruption (Bhattacharya, Montiel, and Sharma, 1997).

\section{References}

Adrianivo, M. \& Yartey, C. A. (2009). Understanding the growth of African financial markets. IMF Working Paper 09/182 (Washington: International Monetary Fund). 
Benassy-Quere, A., Coupet, M., \& Mayer, T. (2007). Institutional developments of foreign direct investment. World Economy, 30, pp. 764-82. http://dx.doi.org/10.1111/j.1467-9701.2007.01022.x

Bhattacharya, A., Montiel, P. J., \& Sharma, S. (1997). How can Sub-Saharan Africa attract more private capital inflows? Finance \& Development, 44, pp. 3-6.

Buch, C. \& Kuckulenz, A. (2004). Worker remittances and capital flows to developing countries. Discussion Paper 04-31 (Mannheim: Center for European Economic Research).

Busse, M. \& Groizard, J. L. (2006). Foreign direct investment, regulations, and growth. World Bank Policy Research Working Paper 3882 (Washington: The World Bank).

Chalk, N. A. (2002). The potential role of securitizing public sector revenue flows: An application to the Philippines. IMF Working Paper 02/106 (Washington: International Monetary Fund).

Chami, R. \& Fullenkamp, C. (2009). Remittances in development: A wobbly crutch. Finance \& Development, 46, pp. 2-4.

Chami, R., Fullenkamp, C., \& Jahjah, S. (2005). Are immigrant remittance flows a source of capital for development? IMF Working Staff Paper No. 52 (Washington: International Monetary Fund).

Collins, S. M. \& Bosworth, B. P. (1999). Capital flows to developing economies: Implications for savings and investment. Brookings Paper on Economy Activity No. 1 (Washington: Brookings Institution).

Costa, A., Chamon, M., \& Ricci, L. A. (2008). Is there a novelty premium on new financial instruments? The Argentina experience with GDP-indexed warrants. IMF Working Paper 08/109 (Washington: International Monetary Fund).

Dadush, U., Dasgupta, D., \& Ratha, D. (2000). The role of short-term debt in recent crises. Finance \& Development, 37, pp. 1-8.

Dorsey, T. (2008). A capital Story. Finance \& Development, 45, pp. 1-9.

Fajnzylber, P. \& Lopez, H. J. (2007). Closer to home. (3rd ed.). Washington: The World Bank. pp. 23-26.

Gupta, S., Pattillo, C., \& Wagh, S. (2007). Making remittances work for Africa. Finance \& Development, 44, pp. 1-8.

International Monetary Fund (2005). World Economic Outlook, April (Washington: International Monetary Fund).

Kelkar, S. \& Ratha, D. (2009). New paths to funding. Finance \& Development, 46, pp. 1-5.

Lopez-Mejia, A. (1999). Large capital flows: Causes, consequences, and policy responses. Finance \& Development, 36, pp. 1-7. 
Loungani, P. \& Razin, A. (2001). How beneficial is foreign direct investment for developing countries? Finance \& Development, 38, pp. 1-6.

Lucas, R. E. (1990). Why doesn't capital flow from rich to poor countries. American Economic Review, Paper and Proceeding, 80, pp. 92-96.

McDonald, C., Treichel, V., \& Weisfeld, H. (2006). Enticing investors. Finance \& Development, 43, pp. 1-7.

Mishra, D., Mody, A., \& Murshid, A. P. (2001). Private capital flows and growth. Finance \& Development, 38, pp. 1-7.

Mody, A. \& Srinivasan, K. (1998). Japanese and US firms as foreign investors: Do they march to the same tune? Canadian Journal of Economics, 31, pp. 778-99. http://dx.doi.org/10.2307/136491

Naude, W. A. \& Krugell, W. F. (2007). Investigating geography and institutions as determinants of foreign direct investment in Africa using panel data. Applied Economics, 39, pp. 1223-33. http://dx.doi.org/10.1080/00036840600567686

Prasad, E., Rajan, R., \& Subramanian, A. (2007). The paradox of capital. Finance \& Development, 44, pp. 1-9.

Ratha, D. (2009). Remittances in development: A lifeline to poor countries. Finance \& Development, 46, pp. 1-2.

Ratha, D. (2005). Remittances: A lifeline for development. Finance \& Development, 42, pp. $1-5$.

Reddy, Y. V. (2007). Point of view: Converting a tiger. Finance \& Development, 44, pp. 20-23.

Regional Economic Outlook (2010). Sub-Saharan Africa: Back to high growth? Regional Economic Outlook (April 10) (Washington: International Monetary Fund).

Reinhart, C. \& Reinhart, V. (1998). Some lessons for policymakers who deal with the mixed blessings of capital inflows. in Capital flows and financial crises, ed. by Miles Kahler (Ithaca, New York: Cornell University Press).

Sayeh, A. (2011). Capital flows to the final frontier. IMFdirect, (May 24) (Washington: International Monetary Fund).

Selassie, A. A., Clement, B., Tareq J. M., \& di Bella, G. (2006). Designing monetary and fiscal policy in low-income countries. IMF Occasional Paper No. 250 (Washington: International Monetary Fund).

Summer, L. (2000). International financial crises: Causes, prevention, and cures. American Economic Review, Papers and Proceedings, 90, pp. 1-16. http://dx.doi.org/10.1257/aer.90.2.1 


\section{Macrothink}

Business and Economic Research

ISSN 2162-4860 2011, Vol. 1, No. 1: E2

Suro, R., Bendixen, S., Lowell, B. L., \& Benavides, D. C. (2002). Billions in motion: Latin immigrants, remittances, and banking (Washington: Pew Hispanic Center and Multilateral Investment Fund).

Vijaya, R., Gelb, A., \& Shah, M. K. (2009). Africa's private sector: What's wrong with the business environment and want to do about it? (Washington: Center for Global Development).

\section{Copyright Disclaimer}

Copyright reserved by the author(s).

This article is an open-access article distributed under the terms and conditions of the Creative Commons Attribution license (http://creativecommons.org/licenses/by/3.0/). 